\title{
Comparison of Commercial bank Savings Deposit Interest Method
}

\author{
Hongjuan WANG \\ Linyi university, linyi, China
}

\begin{abstract}
The author of this paper interprets the calculation of interest about the regular savings deposits and demand savings deposits in two aspects: the traditional 30 days interest method and the actual number of days of interest method. It aims to study which method is more suitable to the calculation of the deposit interest. Through the comparison of two methods, the author illustrates with example and further determines the rationality of the actual number of days of interest method.
\end{abstract}

KEYWORD: Unit deposits; Savings deposits; Interest-bearing base

The deposit is commercial banks' activity, by which they can absorb the social idle funds in credit way. It is a liability business of commercial bank's main source of funds. It is very important for banks, because it turns into revenues and gains. Deposit can be divided into units of deposits and savings deposits according to source of bank finance. Unit deposit refers to that depositors open a savings account in the bank and deposit the money in the name of organs, groups of depositors, army, enterprises, institutions or other organizations. Personal(saving) deposit is the money in the bank in the name of a natural person by his identity, which is divided into demand savings deposits and regular savings deposits. For regular savings deposits, the interest calculation is simpler than demand savings deposits. This paper focuses on the analysis of demand savings deposit interest calculation.

\section{REGULATIONS ON SAVINGS DEPOSIT INTEREST IN A COMMERCIAL BANK}

\subsection{The basic formula of savings deposit interest}

Interest=principal $\times$ deposit $\times$ interest $\times$ rate

The interest rate is expressed by the annual interest rate, interest rate, interest rates in three forms. In the use of interest rate we should pay attention to the relationship, the conversion relationship between the annual interest rate, interest rate and interest rate, in addition we should maintain consistency between period and the interest rate. The storage period of "head not tail ", includes the days from the deposit day to the day before withdrawal day, or includes the days from the day before the deposit day to the withdrawal day. Savings deposits are subject to the calculation of "the year, the month, and the day". There is the whole year from the deposit date to the same day in the next year. There is the whole month from the deposit date to the same day in the next month. If the day of the expiry or withdrawn does not exist, or the month of the expiry or withdrawn does not exist, the last day of the due or withdraw month is the expiration date.

\subsection{Two kinds of interest-bearing deposits}

At present, in the commercial banks, there are two kinds of different interest methods, namely, the actual number of days and traditional 30 days per month .The difference between the two methods is that the different interest-bearing base. The traditional 30 days per month interest method refers to that there is 360 days in a year, no matter how many days in a month, maybe 30 days or 31 days, 28 days, 29 days. According to 360 days in a year, daily interest rate is the year interest rate divided by 360 , the bank will meet the situation that monthly interest will be less a day if there is 31 days in a month .In less than 30 days February, depositors would get one or two days of interest. The actual number of days of interest is that there is 365 days (366 days in leap years) in a year. The actual number of days per month is the days for the Gregorian calendar. Demand deposits interest rate is the year interest rate divided by 365(or366). The calculation of interest is relatively close to the actual, more fair and reasonable. 


\section{LITERATURE REVIEW}

The financial accounting, by Xiaofeng Wang was published by the northeast university of finance and economics press in 2009. It mentioned the basic formula of the calculation of interest, and paid attention to the calculation of maturity. The rest was the same as the basic formulas expressed in the savings deposit interest of the commercial banks. But in the specific examples, the daily rate was calculated by the interest rate divided by 30 , so we were able to find traces of the traditional 30 days per month. ${ }^{2}$

The bank accounting, by Xuejie Lou, was published by Chemical industry press in 2010. It did not clearly state deposit interest methods. But the traditional 30-days per month was used in the actual application. $^{4}$

The bank accounting, by Long Yue, was published by higher education press in 2010. It did not explicitly put forward to the specific methods of deposit interest. But in the calculation of the interest, the formula was the cumulative JiShu times (the annual interest rate $\div 360$ ) or cumulative JiShu times (the monthly interest rate $\div 30$ ). The cumulative JiShu referred to the amount of money and the quantity, specifically referred to the principal $\mathrm{x}$ deposit. It was clearly see that the savings deposit interest was calculated by the traditional 30 days per month. ${ }^{5}$

The bank accounting, by Xuehong Zhi, was published by Renmin university of China press in 2010. The calculation of the deposit was explained in this book: from the regulation of interest rate conversion, whether more than 30 days, less than 30 days, or leap year, a leap year, the year was calculated at 12 months, 360 days. The traditional 30 days per month was used. ${ }^{6}$

The financial accounting, by Honghua Qian, was published by Shanghai University of finance and economics press in 2011. It put forward to: the various savings deposit was calculated at 360 days all the year, no matter more than 30 days, less than 30 days, PingYue and leap month, and calculated at 30 days per month, 30 and 31 as the same day, and had carried on the concrete analysis. The author supported the traditional 30 days per month. ${ }^{7}$

The bank accounting, by Yuanlin Ding, was published by Lixin accounting press in 2013. The calculation about savings deposition this book had not made a special instruction. But the traditional 30 days per month was involved in the formula that was "interest $=$ JiShu $\times$ monthly interest rate/ 30". And the viewpoint of Yuanlin Ding was the same as Xiaofeng Wang. ${ }^{8}$

From the above analysis, we generally support the traditional 30 days per month. In theory they basically support this method. During my personal teaching process, different version, different press and different writer, none of which involves the theory of the actual number of days. So in the actual work?

China CITIC Bank credit management department general manager Jianlin Sun in "financial accounting" entitled "bank interest bearing base should be a year 365 days fair and reasonable" article, supports the interest calculation according to the actual number of days. ${ }^{1}$

The people's Bank of China regulates: personal demand deposits have two ways in interest calculation method- pre-determined JiShu method and specific interest method, simply which is to calculate interest according to 360 or 365 days. Predetermined JiShu method applies to calculate interest for the change of the savings deposit balance during the period of interest-bearing. The people's bank of China requires Banks can choose interest calculation method according to oneself circumstance, no matter what area, no matter which province.

The people's bank of China puts forward to the specific provision: two interest methods can freely choose, but Jianlin Sun supports the actual number of days per month.

Theory is not accordance with practical work about savings interest. Through the investigation about banks in linyi, we found that most banks still did not use the actual number of day's interest method. So this becomes the starting point of the thesis writing.

\section{APPLICATION OF COMMERCIAL BANK DEPOSIT INTEREST IN PRACTICE}

\subsection{Regular savings deposits and demand savings deposits}

For the regular savings deposits, interest shall be calculated according to the basic formula. The principal, the deposit period, interest rates are easily identified. The bank pays interest in the appropriate savings deposits rate listed on the opening date, not sectional interest. But not all savings customers are to draw on the due date, but due sometime in the future to draw, which is considered overdue payment. Interest calculation both regular savings deposits and demand savings deposits are involved in this process.

Example 1: a customer on February 28, 2011 lump fixed deposit 10000 dollars for the six months, assuming interest rates are $1.89 \%$, the expiration date is August 28, 2011, and withdrawal date is November 1, 2011. Assume that on November 1, 2011, the current savings account interest rate is $0.72 \%$. Calculation of interest should be paid to the customer.

Solution 1 (traditional 30-day interest method)

First, periodic interest payment $=10000 \times 6 \times$ $(1.89 \% \div 12)=94.5$ 
And total interest payable is as follows:

Interest payable $=10000 \times 6 \times(1.89 \% \div 12)+63$ $\times(10000+94.5) \times(0.72 \% / 360)=94.5+12.72=107.22$

Solution 2(actual days interest method)

First, periodic interest

$=10000 \times 6 \times(1.89 \% \div 12)=94.5$

And total payable interest is as follows:

Interest payable $=10000 \times 6 \times(1.89 \% \div 12)+$ $65 \times(10000+94.5) \times(0.72 \% / 360)$

$=94.5+13.12=107.62$

Table 1: interest in overdue withdrawal

\begin{tabular}{|c|c|c|}
\hline Interest method & $\begin{array}{c}\text { Actual number of } \\
\text { days }\end{array}$ & $\begin{array}{c}\text { traditional 30 } \\
\text { days }\end{array}$ \\
\hline periodic interest & 94.5 & 94.5 \\
\hline Current interest & 13.12 & 12.72 \\
\hline Total interest & 107.62 & 107.22 \\
\hline
\end{tabular}

The answer can be seen from the above: Interest is composed of two parts, the first part is the regular deposit interest and the second part is the overdue payment of interest on the part of the current savings. Interest are the same on the first part, the second part of the interest, Auto save for regular savings deposits should be in accordance with the compound interest, It is very easy to be overlooked, the difference between two kinds of interest can affect storage period and the interest paid to depositors of commercial banks.

The regular savings deposit withdrawal ahead of term: Regular savings deposits have three kinds of methods withdrawal: due withdrawal, expired withdrawal, and withdrawal ahead of term. If all deposit draw in advance for the regular savings deposit, commercial banks pay interest on listing demand savings account interest rate.

Example 2: depositor Li Ming on January 20 lump fixed deposit of 860 Yuan for one-year in savings deposits. He applies or withdrawal ahead of term on May 18, as agreed by the audit process, pay interest at current rates, monthly interest rate of 2.1 per thousand, February 28 days. The interest payable is calculated.

Solution 1 (traditional 30-day interest method)

period $=3 \times 30+28=118$

interest $=860 \times 118 \times(2.1$ per thousand $\div 30)=7.10$

Solution 2 (actual days interest method)

period $=12+28+31+30+17=118$

interest $=860 \times 118 \times(2.1$ per thousand $\div 30)=7.10$

From the above two answers, we can see the exactly same data either actual interest method or traditional 30-day interest method, which will not have any impact on banks. In answer 1 , however, is the actual number of days per month of the Gregorian calendar, that is, actual interest method and in answer 2, each month 30 days, that is, the traditional 30-day interest method, it is clear that there is no difference in interest paid to depositors between two kinds of ways interest.

Example 3: If the deposit date to July 31, and withdrawal day to November 1 , the rest exactly the same information, how much interest you would pay that?

Solution 1 (traditional 30-day interest method)

period $=3 \times 30+1=91$

interest $=860 \times 91 \times(2.1$ per thousand $\div 30)=5.48$

Solution 2 (actual days interest method)

period $=31+30+31+1=93$

interest $=860 \times 93 \times(2.1$ per thousand $\div 30)=5.60$

Table 2: interest in withdrawal ahead of term

\begin{tabular}{|c|c|c|}
\hline Interest method & $\begin{array}{c}\text { actual number } \\
\text { of days }\end{array}$ & $\begin{array}{c}\text { traditional 30 days } \\
\text { per month }\end{array}$ \\
\hline periodic interest & 93 & 91 \\
\hline Current interest & 15.6 & 15.48 \\
\hline
\end{tabular}

By contrast example 2, we found that the same savings deposits generate different interest between two kinds of ways interest. Under the same condition, different interest calculation methods, so have different interest. Which method is more reasonable about the interest calculation for banks? It not only does not harm the customers' interest, but also will not affect the interests of the banks. And it reaches equilibrium between the customers' interest and the banks' interest, realize their benefit maximization. This leads to the conclusion of this paper.

\subsection{Demand savings deposits}

The demand savings deposit interest calculation is simpler, basically carried out in accordance with the interest calculation formula.

Example 4: a customer on February 28, 2011 the demand savings deposit 10,000 dollars, assuming interest rates are $0.89 \%$, Calculation of interest should be paid to the customer at August 28, 2011.

Solution 1 (traditional 30-day interest method)

Interest payable as follows:

$=10000 \times 6 \times 30 \times(0.89 \% \div 360)=44.5$

Solution 2(actual days interest method)

Interest payable as follows:

$=10000 \times(31+30+31+30+31+28) \times(0.89 \% \div 360)$ $=10000 \times 181 \times(0.89 \% \div 360)=44.75$

Above summarizing several examples, we can see the same item savings deposit interest differences under different interest way. Under the actual number of days method, the amount of interest is more, namely the Banks pay more to the customer's interest, which realize the customers' benefit maximization. At present the banks do not have the same method in the calculation of interest. This also explains why the customer can choose banks according to the actual number of day method. 


\section{THE CONCLUSIONS}

Two different forms of interest, that is the actual interest method and the traditional 30-day interest method, currently exist in commercial banks. Commercial banks pay different interest to depositors in different interest ways, which will result in different costs and different accounting profit for commercial banks.

The people's Bank of China regulates: personal demand deposits have two ways in interest calculation method- pre-determined JiShu method and specific interest method, simply which is to calculate interest according to 360 or 365 days. Predetermined JiShu method applies to calculate interest for the change of the savings deposit balance during the period of interest-bearing. So the bank mainly takes Pre-determined JiShu method to calculate interest on demand savings accounts, including a demand deposit, notice deposit. While for the regular savings deposit, including small lump, the term has the withdrawal, interest, timedemand optional. Banks adopt specific interest method to calculate the interest.

The people's bank of China requires banks can choose interest ways according to its circumstance, in Linyi, for example, ICBC and other banks take 365-dayinterest method; Bank of China, Shanghai Pudong Development Bank and other banks take 360-day interest method.

Two kinds of interest have a little effect on the return of depositors. But through the second parts of the data there is a certain difference on the return of depositors. How much difference will be caused? We exemplify the interest difference formula: in the case of unchanged principal, days and interest rates, when interest bearing base is 360 days and 365 days, the interest margin $=$ principal $\times$ days $\times$ rate $\times(1 / 360-$ $1 / 365)$. If other factors remain unchanged, the greater the difference between the principal amounts, interest margin is greater. The same principal and interest rates unchanged, the longer the period, the margin of interest is greater. The interest margin due to two kinds of interest directly determines the amount of commercial bank profit table "interest", which affects the bank's net interest income, thus further affects the commercial banks operating income, and ultimately affects the operating profit and total profit. So interest differences have an impact on the banks due to two kinds of interest.

So far two kinds of interest is a certain basis, what kind of interest is more reasonable?

First of all, in theory, the actual number of day method conforms to the accrual basis and the principle of comparability. The accrual basis refers to the occurrence of accrual basis to determine the current revenues and expenses. Now from the perspective of a day, according to the actual number of day method, every day of every month will have corresponding revenues and expenses, compared to traditional 30 days per month method. Both 31 day and 30 day as a monthly one day, which produce such corresponding revenues and expenses, that the monthly accounting information every day is incomparable. In less than 30days, actually only 28 or 29 days, but in accordance with the traditional 30 days per month method we find two days corresponding income and expenses and couldn't find the corresponding date, which also can make the accounting information incomparable.

Secondly, from the point of actual work, bank credit management department general manager Jianlin Sun clearly supports the actual number of days method.1 People with actual work experience have the most persuasive speaking. Real knowledge comes from practice.

In addition, the existing environment of the traditional 30 day per month method changed. China CITIC Bank credit management department general manager Jianlin Sun in "financial accounting" entitled "bank interest bearing base should be a year 365 days fair and reasonable" article, supports the interest calculation according to the actual number of days. 1 In addition, China's commercial banks calculate interest according to360 days, which is because in old past abacus calculation of interest is not convenient, the integer 360 than 365 more convenient. Now, with the development of computer technology, the development of information society, the interest calculation can be carried out by computer, so no matter how the data, regardless of whether the integer, computer replaces the manual to calculate the deposit interest, reducing the previous calculation process. So it should consider the interest in accordance with the actual 365 days or 366 days. Therefore, the actual interest method is more close to reality, which is a kind of development trend in the future.

\section{REFERENCES}

[1] Jianlin Sun. Bank interest bearing base should be a fair and reasonable financial accounting for 365 days, 2007.

[2] Xiaofeng Wang, The financial accounting, the northeast university of finance and economics press, 2009.

[3] Ying He, Honghua Qian. The bank accounting. Shanghai: Fudan University press, 2010.

[4] Xuejie Lou. Bank accounting. Chemical Industry Press, 2010.

[5] Long Yue. The bank accounting, higher education press, 2010.

[6] Xuehong Zhi.The bank accounting, Renmin university of China press, 2010.

[7] Honghua Qian. The financial accounting, Shanghai University of finance and economics press, 2011.

[8] Yuanlin Ding. The bank accounting, Lixin accounting press, 2013. 